bound to ignore the tax-avoidance aspects of outright gifts of income-producing property to family members. But this does not mean that all other intra-family tax avoidance schemes should be treated with kid gloves. Whenever possible, the courts should prevent inroads on the ability-to-pay principle of the revenue code. By accepting the Tax Court's rationale in the Skcmp and Browon cases, they will be able to suppress the gift and leaseback's vast tax-avoidance potential. ${ }^{33}$

\title{
FIRING EMPLOYEES FOR INNOCENT MISSTATEMENTS AT UNION MEETINGS*
}

For a union to operate effectively, its members must be able to discuss union affairs free from employer restraints. Recognizing this fact, both the NLRB and the seventh circuit have classified innocent employee misstatements on union-management relations as concerted union activity protected by the Labor Management Relations Act. ${ }^{1}$ They have held that the discharge of an

33. The simple leaseback principle has also played a major role in modern corporate financing. By selling business property to tax-exempt institutions and immediately leasing the property back, corporations interested in borrowing funds have been able to achieve considerable financial advantage, and in no small way reduce their income taxes. For leaseback rentals are calculated to amortize the sales price-the "loan"-as woll as to pay an amount slightly above the current interest rate. The rentals are deducted under \$23(a). Had the corporation borrowed the money, it would only be able to deduct interest payments, not repayment of the principal. See Cary, Corporate Financing Throngh The Sale and Lease-Back of Property: Business, Tax and Policy Considerations, 62 Harv. L. Rev. 1, 17 (1948); Note, 98 U. of PA. L. Rev. 696, 698 (1950). See also Armston v. Commissioner, 12 T.C. 539 (1949), for realistic judicial treatment of this device.

Title III of the Revenue Act of 1950, Pub. L. No. 814, 81st Cong., 2d Sess., restricts somewhat the use of the sale and leaseback. Sections $421-424$ provide for taxing the heretofore tax-exempt institution on the rentals of a lease for more than five years when the institution has incurred an indebtedness connected with acquiring or improving the property to be leased. The amount of rent included in the gross income of the institution is restricted to the same proportion of the rents as the borrowed funds used to finance the purchase or improvement of the income-producing property bear to the adjusted basis of such property. Apparently the act does not strike at leasebacks where the tax-exempt institution has sufficient funds to finance the purchase of the property without borrowing.

* NLRB v. Atlantic Towing Co., 180 F.2d 726 (5th Cir. 1950).

1. Labor Managenent Retations Act, 1947, 61 Stat. 136, 140 (1947), 29 U.S.C. $\S \S 157,158$ (Supp. 1948) [hereinafter cited as LMRA]. The pertinent sections are the following:

"Sec. 7. Employees shall have the right to self-organization, to form, join, or assist labor organizations, to bargain collectively through representatives of their own choosing, and to engage in other concerted activities for the purpose of collective bargaining or other mutual aid or protection, and shall also have the right to refrain from any or all of such activities. ... 
employee for making such misstatements is an unfair labor practice under section $8(a)(1)$ or $8(a)(3) .^{2}$ A recent fifth circuit decision, however, threatens to check effective union discussion by permitting employer sanctions on unintentionally false union speech.

In NLRB v. Atlantic Towing Co., ${ }^{3}$ an employee was fired for making a false report at an AFL meeting. He had claimed that the company manager urged a CIO representative to beat the AFL in organizing the company's workers. ${ }^{4}$ In the ensuing unfair labor practice hearing, the Board found that the employee's misstatement was not intentional and that his discharge was therefore a violation of $8(\mathrm{a})(3) .^{5}$ But the fifth circuit reversed, ${ }^{6}$ noting that the employee's

"Sec. 8. (a) It shall be an unfair labor practice for an employer-

"(1) to interfere with, restrain, or coerce employees in the exercise of the rights guaranteed in section $7 ; \ldots$

"(3) by discrimination in regard to hire or tenure of employment or any term or condition of employment to encourage or discourage membership in any labor organization: ....."

2. NLRB v. Illinois Tool Works, 153 F.2d 811, 815 (7th Cir. 1946); Westinghouse Electric Corp. \& United Electrical, Radio \& Machine Workers of America (C.I.O.), 77 N.L.R.B. 1058 (1948).

The Illinois Tool case held that the discharge of an editor of a union bulletin for not printing a retraction of an inaccurate comparison of company vage rates with those of nearby plants was a violation of section $8(a)(1)$. In that case the court found that at the time the bulletin was printed, the editor was "unaware of the existence of any inaccuracy."

In the Westinghouse case, the Board held that the discharge of an employee who had made untrue statements to his fellow employees that wage rates were higher at another plant of the company was a violation of sections $8(a)(1)$ and $8(a)(3)$. In its opinion the Board stated: "For all the record shows, [the employee] did not carefully investigate the facts before asserting that the wage rates were higher at $\operatorname{Lima}$, but neither did he make those inaccurate statements with any malice or deliberate intention to falsify."

3. 180 F.2d 726 (5th Cir. 1950).

4. The facts brought out in the NLRB hearing were these: the CIO agent telephoned the manager for permission to talk to the company's workers. Thereupon the manager called the docks to announce the agent's arrival and ordered that the agent be "accorded every courtesy." The employee overheard the telephone conversation, and when he went down to the docks, learned that the CIO agent had just left. The Board felt that the instruction that the CIO agent be accorded every courtesy and the speed with which the CIO's organizational attempt followed the conversation, "may well have served to confuse the thoughts of [the employee] as to what was said, what was intended, and what was done..." Atlantic Towing Company and Seafarers International Union, AFL, 75 N.I.R.B. 1169,1171 (1948).

5. Id. at 1176. Member Gray dissented from the Board's opinion. He felt that employees are protected from employer discrimination in their discussions of organizational matters, but that such protection does not extend to statements made, as in this case, at an open meeting attended by management representatives.

6. NLRB v. Atlantic Towing Co., 180 F.2d 726 (5th Cir. 1950). Originally the Fifth Circuit unanimously sustained the Board's reinstatement order, saying: "The Beard found that he [the employee] made a bona fide statement of his recollection of the conversation; and we are bound to enforce the order, since on the whole record there is substantial evidence to support this finding, even though we, or some other fact-finding 
false report implied that the employer had violated the labor law. ${ }^{7}$ Such a false statement, it held, was a proper ground for dismissal even if the speaker honestly believed what he said. ${ }^{8}$

By permitting discharges for honest misstatements, the Atlantic Toreing rule jeopardizes union activity protected by the LMRA. To increase their bargaining power by acting in concert, union members must be free to voice their grievances and to plan joint action in support of one another. Limited in their access to accurate information as to the company's policies, they must often act on unverified suspicions and inferences. ${ }^{9}$ If the Atlantic Tozving rule is applied to any false statements about the employer, fear of discharge for accidentally erroneous statements regarding employer-union relations may seriously curb legitimate discussion vital to union activities. And even if the Atlantic Tozeing rule is limited to statements which imply an employer violation of law, desirable union speech might still be curtailed. Members of unions must be free to discuss employer violations in order to enforce rights guaranteed to them by the Act. Moreover, in an area so honeycombed with regulations, a

tribunal, might fairly and reasonably have found the contrary." NLRB v. Atlantic Towing Co., 179 F.2d 497, 499 (5th Cir. 1950).

On petition for rehearing, however, the court in a per curiam opinion, Chief Justice Hutcheson dissenting, reversed the Board's decision and denied its petition for enforcement. NLRB v. Atlantic Towing Co., 180 F.2d 726 (5th Cir. 1950).

7. NLRB v. Atlantic Towing Co., 180 F.2d 726 (5th Cir. 1950). The violation implied by the employee's report probably involved section $8(a)(2)$ of the LMRA which provides: "It shall be an unfair labor practice... to dominate or interfere with the formation or administration of any labor organization or contribute financial or other support to it: ...."

The decision does not indicate why the court attached significance to the fact that the employee's report implied a violation of the Act. In view of section 8(a) (4), discussed p. 1539 infra, this fact would seemingly strengthen the employee's casc.

8. "The statement falsely charged the company with a violation of the labor law. Respondent had the right to discharge Hendrix for making the statement, irrespective of whether Hendrix knew or did not know that the statement was false. It was not an unfair labor practice to discharge him for making it." Ibid.

9. There is often no way union members can ascertain what the employer's policies actually are. In small concerns such policies are usually made by one man, seldom recorded, and subject to change without notice. And although unions in larger corporations may have better trained leadership, here too, in order to gain advantages in bargaining with the union, corporation management will often keep policies secret. Thus both of the parties must frequently act upon guesses as to what the other's policy is.

See the Board's statement in the Atlantic Tozving case: ". . . [T] ruth is not always apparent, and men are influenced in their conduct by rumors, by inferences from known facts, and even by mere suspicions which may ultimately prove to be unfounded but which the exigencies of the situation do not permit of verification; it would, therefore, be decidedly unrealistic to hold that the organizational and concerted activities envisaged by the Act exclude the utterance by employees of honestly believed statements of fact or opinion, which, in some cases, may actually be unfounded in fact." Atlantic Towing Company and Seafarers International Union, AFL, 75 N.L.R.B. 1169, 1172 (1948). 
good many penetrating statements about labor-management relations could hardly avoid implying a violation of law. ${ }^{10}$

The Atlantic Towing rule contains another threat to free union activity. It provides a particularly effective cloak for discriminatory discharge of aggressive union members. Employers who have sought to use other types of conduct to disguise anti-union discrimination have frequently failed because of proof that employees less aggressive on behalf of the union were not similarly disciplined for similar conduct.11 But nearly all recorded examples of employee misstatements are contained in union speech only. Since the NLRB will be unable to compare the employer's reaction to non-union misstatements with his attitude towards union misstatements, it will have a difficult time proving that the misstatement was merely a pretext for discrimination.

The Atlantic Towing decision also seems questionable in view of Section 8 (a) (4) of the LMRA. This provision forbids discrimination against an employee because he has filed unfair labor practice charges or testified before the NLRB-even though his statements were completely unfounded. ${ }^{22}$ It was enacted to prevent employer retaliation which would make employees afraid to bring grievances before the Board. ${ }^{13}$ But union discussion of the employer's practices should-and generally does-precede the filing of formal charges against him with the NLRB. Thus, by allowing an employer to discharge his employees for statements normally made before the union seels the help of the Board, the Atlantic Towing rule may permit him to accomplish the very thing section $8(a)$ (4) was designed to prevent.

In addition, administration of the Atlantic Towing rule will involve the Board in complex problems of fact finding. Since, if the employee's statements were true, his discharge would be unfair labor practice, the Board will be

10. Frequently union meetings discuss such questions as whether the employer favors one union over another, promotes non-union men rather than union men, gives union men less desirable assignments than non-union men, or does not show good faith in collective bargaining. Any allegation that the employer followed such practices vould imply a violation of the LMRA.

11. E.g. Edward G. Budd Mfg. Co. v. NLRB, 138 F.2d 86 (3rd Cir. 1943), cert. denied 321 U.S. 778 (1944) ; American Mffg. Co., 5 N.L.R.B. 443 (1938) ; Bradford Dyeing Association, 4 N.L.R.B. 604 (1937).

In cases of alleged anti-union discrimination, the NLRB must decide whether the reasons given by the employer for his actions against the union member are his real reasons or only a pretext to weaken the union. The NLRB makes this determination by comparing the employer's policy in the case before it with his past policies. If the employer is applying stricter rules in the present case than he has in similiar cases in the past, this double standard will be taken as evidence of anti-union discrimination. See generally

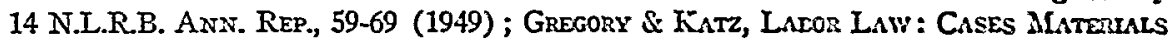
AND Consuents, 628-632 (1948).

12. Burnside Steel Foundry Co., 69 N.L.R.B. 128 (1946); Kramer Co., ef al., 29 N.L.R.B. 921,935 (1941) ; Poe MIfg. Co., 27 N.L.R.B. 1257 (1940).

13. Sen. Rep. No. 573, 74th Cong., 1st Sess. 12 (1935). See also 1 CCH Lab. Law Rep. II 2240 (1950). 
forced to determine the truth of a wide variety of statements. In many areas there is no precise truth; $; 4$ in other areas the truth may lie between the claims of the parties. Thus the Board will be forced to decide the difficult question whether the employee's statements were close enough to the truth to be protected.

Moreover, the Atlantic Towing rule is not really necessary to protect the employer. Discharge of an employee for his statements will hardly convince anyone that they were untrue. The employer's guaranteed rights of free speech $^{15}$ better enable him to counteract false statements. ${ }^{10}$

The sounder policy, then, seems to be that pursued by the seventh circuit and the NLRB. ${ }^{17}$ The discharge of a speaker for Union speech, however untrue, should be regarded as an unfair labor practice so long as the speaker did not have a deliberate intention to falsify. Once the Board is satisfied that a misstatement was made in the course of union or other concerted activity, the burden of proving such deliberate intention should lie on the employer. Only in this way can the free interchange of ideas basic to a sound labor movement be protected.

14. See, e.g. Bettcher Manufacturing Co., 76 N.L.R.B. 526 (1948). When the cmployer, at a union meeting, offered to show his books in order to prove his inability to raise wages, an employee retorted that the books could easily be juggled. The employer fired the employee on the grounds that the employee had in effect called him a "crook and a liar." Without deciding that such was the implication of the employee's statement, the NLRB decided that the statement was privileged as concerted activity. It thus avoided entering the controversial realms of accounting to determine who was speaking the truth.

15. The employer's right of free speech to employees was first established in NLRB v. Virginia Electric \& Power Co., 314 U.S. 469 (1941). As long as the employer does not coerce or bribe the employee in the excercise of rights protected by $\$ 7$, the employcr “. . . may descend to vilification, false statement or exaggeration and still be protected in his right of free speech." NLRB v. Brandeis \& Sons, 145 F.2d 556, 566 (8th Cir. 1944).

On employer free speech under both the National Labor Relations Act and the Labor Management Relations Act, see generally, 2 Teller, Labor Disputes ANd Coluective BARGAINING $\$ 252$ (free speech), §286 (anti-union propaganda) (1940, Supps, 1947, 1950) ; Cox, Some Aspects of the Labor Management Relations Act, 1947, 61 HAkv. L. REv. 1, 274 (1948) ; Note, 58 YaLe L.J. 165 (1948).

16. Traditionally, the antidote for a misuse of free speech has been more free speech, not attacks upon the speaker. In the present case, the employer exercised his right of frce speech to counteract what he felt were misrepresentations of fact about management. After firing the employee, the manager called a meeting of the employees and asstured them that both he and the company recognized their right to join any union they wished and promised that the company would deal with the union of their choice. See testimony of Frank Spenser, Brief for Petitioner, Appendix, NLRB v. Atlantic Towing Company, 180 F.2d 726 ( 5 th Cir. 1950).

17. See note 2 supra. 